2007

\title{
Endless Emergency: The Case of Egypt
}

Sadiq Reza

New York Law School, Sadiq.Reza@nyls.edu

Follow this and additional works at: https://digitalcommons.nyls.edu/fac_articles_chapters Part of the International Law Commons

\section{Recommended Citation}

New Criminal Law Review, Vol. 10, Issue 4 (Fall 2007), pp. 532-553

This Article is brought to you for free and open access by the Faculty Scholarship at DigitalCommons@NYLS. It has been accepted for inclusion in Articles \& Chapters by an authorized administrator of DigitalCommons@NYLS. 


\section{ENDLESS EMERGENCY: THE CASE OF EGYPT}

Sadiq Reza*

The Arab Republic of Egypt has been in a declared state of emergency since 198I and for all but three of the past fifty years. Emergency powers, military courts, and other "exceptional" powers are governed by longstanding statutes in Egypt and authorized by the constitution, and their use is a prominent feature of everyday rule there today. This essay presents Egypt as a case study in what is essentially permanent governance by emergency rule and other exceptional measures. It summarizes the history and framework of emergency rule in Egypt, discusses the apparent purposes and consequences of that rule, mentions judicial limitations on it, and notes the many targets of $i$ ts exercise over the years, particularly the government's two most prominent and persistent groups of opponents: Islamists and liberal political activists. It also explains how the country's March 2007 constitutional amendments, much decried by bumanrights organizations inside and outside Egypt, further entrench emergency rule there. The thesis of the essay is that the existence and exercise of emergency powers have been far from exceptional in Egypt; instead they have been a vehicle for the creation of the modern Egyptian state and a tool for the consolidation and maintenance of political power by the government.

This essay considers the Arab Republic of Egypt as a case study in the extended use of emergency powers. Egypt offers a rich study of the topic

*Professor, New York Law School. I thank Nathan Brown, Kristen Stilt, Said Haddad, and Tamir Moustafa for guidance and comments, Moumita Rahman, Peter Hanschke, and Chloe McRae for research assistance, Markus Dubber and Lindsay Farmer for inviting me to participate in this workshop, and Sarah Devotion Garner, formerly at the Law Department of the American University in Cairo, for an English translation of Egypt's 1958 Emergency Law. Arabic texts of the Egyptian laws and decrees cited herein are available via subscription to the Legislation and Developments Information Service (LADIS), at http://www.tashreaat.com.

New Criminal Law Review, Vol. 10, Number 4, pps 532-553. ISSN 1933-4192, electronic ISSN 1933-4206. (C) 2007 by the Regents of the University of California. All rights reserved. Please direct all requests for permission to photocopy or reproduce article content through the University of California Press's Rights and Permissions website, http://www.ucpressjournals. com/reprintInfo.asp. DOI: 10.1525/ndr.2007.10.4.532. 
for several reasons. Emergency rule has been operative in Egypt for most of the past one hundred years and continuously since 1981. This rule has been effectuared through a dizzying array of exceptional measures and courts, and it has been exercised robustly. Information about this rule is available and plentiful, from sources inside the country and outside of it: political and intellectual life in Egypt is vibrant, human-rights organizations in the country are active and vocal, and Egypt is likely the moststudied and best-known Arab country in the West. There is also general consensus, at least among nongovernmental observers, over the effect if not the ultimate purpose of emergency rule in Egypr-to wit, the consolidation of state power in the presidency and the suppression of popular opposition. Nor is there disagreement that the form of government in which Egypt's emergency rule exists, and which it perpetuates, is not a constitutional democracy but an authoritarian regime.

Much recent literarure on emergency rule and powers focuses on their theory and operation in democratic societies. ${ }^{1}$ The rationale for this focus is apparently that in authoritarian regimes, concerns about individual liberty do not compete with concerns about state power in the way they do in democracies (if they do at all). ${ }^{2}$ This may be so; but of course it does not mean there is nothing to learn from the use of emergency rule and other exceptional powers in authoritarian regimes, particularly in one that has democratic aspirations, as Egypt does. Indeed, perhaps at once the most authoritative and provocative reading of the past half-century of emergency rule in Egypt is that the regime's exercise of exceptional authority to suppress political opposition, in particular its use of emergency state security courts and military courts, has enabled Egypt's

I. See, e.g., Oren Gross \& Fionnuala Ní Aoláin, Law in Times of Crisis: Emergency Powers in Theory and Practice (2006); David Dyzenhaus, The Constitution of Law: Legality in a Time of Emergency (2006); Symposium: Extraordinary Powers in Ordinary Times, 87 B.U. L. Rev. 289-346 (2007).

2. See, e.g., Gross \& Ní Aoláin, supra note I, at 3:

[A] uthoritarian regimes are not faced with the tragic choices that violent emergencies present to democracies. For the former, the only significant parameters by which to evaluate the state's response to the violence are efficiency, allocation of resources, and the political and perhaps physical survival of the regime. No real tension exists, nor can one exist, between liberty and security, because security is everything and liberty does not count for much, if at all. Such ... regimes are motivated by reason of stare arguments that are reminiscent of those put forward by political realists. For democracies, however, the story and calculus are different. 
ordinary judiciary, particularly its Supreme Constitutional Court, to pursue a liberal agenda. ${ }^{3}$

At the same time, Egypt provides a textbook example of familiar features of emergency rule, such as its direct evolution from martial law, under colonial masters no less, and the transformation of temporary measures to permanent ones. ${ }^{4}$ The most dramatic and far-reaching of these transformations in the Egyptian case in fact occurred just recently, in March 2007, when Egypt's parliament adopted constitutional amendments that embedded specific emergency powers in the country's constitution. Egypt's experience also demonstrates how emergency rule can empower the executive branch at the expense of other branches of government, as well as how other branches, particularly the judiciary, can limit that power: over the decades, Egypt's ordinary judiciary has often, though not always, provided a check on presidential exercises of emergency powers. And finally-if more reasons to study it are neededemergency rule in Egypt is directly linked, as both cause and effect, to the rise of Islamist violence in Egypt, and beyond. Among the political opponents of the regime whose activities have been stifled by Egypt's emergency powers are Sheikh Omar Abdel Rahman, now serving a life sentence in U.S. federal prison for a 1993 plot to destroy landmarks and tunnels in New York City, and Ayman al-Zawahiri, best known these days as Osama bin Laden's deputy and a speaker in periodic audio and video tapes that threaten further attacks on Americans and others.

Because this essay considers only Egypt, however, I make no claim about the typicality or atypicality of emergency rule there. Egypt's experience with emergency powers also should not be considered representative of the experience of other Arab, or Middle Eastern, or Muslim states. I do, however, present Egypt as an example of endless emergency-in other words, as a case study in the nature, causes, and consequences of governance by emergency powers and other exceptional measures that is essentially

3. See Tamir Moustafa, The Struggle for Constitutional Power: Law, Politics, and Economic Development in Egypt 8, 175-77 (2007); Nathan J. Brown, The Rule of Law in the Arab World II6 (1997).

4. See, e.g., Mark Neocleous, From Marrial Law to the War on Terror, ro New Crim. L. Rev. 489 (2007) (evolution from martial law); Mark Neocleous, The Problem with Normality: Taking Exception to "Permanent Emergency," 3r Alternatives 191 (2006) (permanence); Nasser Hussain, The Jurisprudence of Emergency 22-32 (2003) (relationship with colonialism). 
permanent. The temporal aspect of the endless emergency in Egypt is obvious; two additional aspects merit identification: endlessness in the scope of emergency powers that have been established or exercised in Egypt, and endlessness in the list of targets against whom they are directed. The endlessness of emergency in Egypt in all three of these aspects-duration, scope, and targets-will be discussed below. Part I sketches the history and framework of emergency powers and other exceptional authority in Egypt. Part II addresses the apparent purpose of the regime's use of those powers, limitations on those powers, and the targets against whom the powers have been directed. Part III offers concluding observations about the role and future of emergency rule in Egypt.

\section{EMERGENCY POWERS AND OTHER EXCEPTIONAL AUTHORITY IN EGYPT: HISTORY AND FRAMEWORK}

\section{A. From British Martial Law to Egyptian Emergency Law}

Emergency rule in Egypt began with martial law under the British, who occupied the country from $\mathbf{I 8 8 2}$ to 1922 . The first declaration of martial law, in 1914, accompanied Britain's assertion of sovereignty over Egyptthe British declared Egypt a "protectorate" that year-and constituted an act of war with the Ottoman Empire, of which Egypt had been a province for four centuries. Pursuant to that declaration, the Egyptian military was given a British governor and military actions were removed from the jurisdiction of the courts; the British also relied on the emergency powers to impose new taxes on the many non-British foreigners who were in Egypt at the time. ${ }^{5}$ The declaration remained in effect through World War I and a 1919 uprising of Egyprian nationalism, and it ended after the British declared the country independent in $1922 .{ }^{6}$

But the newly liberated Egyptian elite apparently considered emergency authority to be as useful as their British protectors had. The 1923 constitution, which was drafted by Egyptian legal scholars and modeled on the Belgian constitution (and would be only the first of several constitutional documents Egypt adopted in the twentieth century before settling on the 1971 constitution that remains in force today), provided for

5. Brown, supra note 3 , at $39,72,82$.

6. Id. at 40 . 
declarations of martial law, and a 1936 Anglo-Egyptian treaty that guaranteed the British a military presence in Egypt allowed the British to request such a declaration. ${ }^{7}$ Hence a 1939 Egyptian declaration of martial law, which was apparently both a concession and a disappointment to the British, who wanted Egypt to declare war against Germany instead (Egypt declined); that declaration lasted until a few days after the end of World War II in $1945 .^{8}$ Martial law was next declared in 1948 , with the outbreak of the first Arab-Israeli War, and it was lifted in 1950 but reimposed in January 1952, after protests over the presence of British troops at the Suez Canal led to the killing of dozens of Egyptians by British troops and riots broke out on the streets of Cairo. ${ }^{9}$ This declaration lasted until June 1956-that is, through the 1952 Free Officers Revolution and the four years of political wrangling that resulted in the election of army colonel Gamal Abdel Nasser as president. But Nasser did not wait long before reimposing martial law, first in November 1956 with the outbreak of the Suez War, and again in 1958 upon the short-lived socialist union with Syria.

By the time of the 1952 declaration, Egyptian critics of martial law had grown in number and power and were calling for the abolition of emergency authority. Nevertheless, in 1954 a law that strengthened the military's emergency powers was enacted. A more comprehensive emergency law followed in 1958 , and it is under that law that the past half-century of emergency declarations have been made. By the time of that law, emergency authority in Egypt reached well beyond strictly military matters; the term "martial law" ( hukm 'urfi) thus gave way to "state of emergency" (halah al-tawari) in the 1958 law. ${ }^{10}$ The 1958 declaration of emergency itself was lifted in 1964 , but a new declaration followed in 1967, upon the outbreak of the Six Day War with Israel. That declaration lasted through the death of Nasser in 1970, the election of President Anwar Sadat and the

7. Id. at 82; Arthur Goldschmidr, Jr., Modern Egypt: The Formation of a Nation State 73 (2d ed. 2004). Egypr's first-ever constitution came in 1882, but it was rendered irrelevant by the British occupation later that year. See Nathan J. Brown, Constitutions in a Nonconstitutional World 26, 36 (2002).

8. Brown, supra note 3, at 82 \& n.59; A. Seif el-Islam, Exceptional Laws and Exceptional Courts, in Egypt and Its Laws 364 (Nathalie Bernard-Maugiron \& Baudoin Dupret eds., 2002).

9. Brown, supra note 3, at 82 ; Seif el-Islam, supra note 8 , at 364; Goldschmidt, supra note 7 , at IOI-O2.

IO. Brown, supra note 3 , at 82 . 
adoption of the current constitution in 1971, the 1973 war with Israel, and beyond. It was finally lifted in 1980 , but a new declaration followed in October 198I, hours after Sadat was assassinated by Islamist militants. That declaration of emergency remains in force today, having been renewed roughly every three years by Sadat's successor and Egypt's current president, Hosni Mubarak. The most recent renewal came in April 2006, but was for only two years; it is therefore due to expire in April 2008.

\section{B. The 1958 Emergency Law}

The 197 I constitution enshrines the power to declare a state of emergency and vests it in the presidency, subject to ratification by Egypt's Parliament, the People's Assembly. The declaration must be "for a limited period," extensions must also be approved by the Assembly, and-the key languageevery declaration must be made "in the manner prescribed by the law." The 1958 Emergency Law thus governs emergency powers and rule in Egypt. Other exceptional authority will be discussed in section $\mathrm{C}$ below, including the system of military courts, which constitute a separate but equally powerful, and equally exercised, realm of executive authority. The March 2007 embedding of specific emergency powers in the constitution will then be addressed in section $D$. Let us first consider the provisions of the 1958 law.

The 1958 Emergency Law authorizes the president to declare a state of emergency "whenever public security or order are threatened." 12 The threat may be from "war [or] a state threatening the eruption of war," "internal disturbances," "natural disasters," or "the spread of an epidemic."13

II. The full text of the constitutional provision reads as follows:

The President of the Republic shall proclaim a state of emergency in the manner prescribed by the law. Such proclamation must be submitted to the People's Assembly within the following fifteen days so that the Assembly may take a decision thereon. In case of the dissolution of the People's Assembly, the matter shall be submitted to the new Assembly at its first meeting. In all cases, the proclamation of the state of emergency shall be for a limited period, which may not be extended unless by approval of the Assembly.

Egypt. const., art. I48 (official English translation available at http://www.sis.gov.eg/En/ Politics/Constitution/Text/04070300000000000I.htm).

12. Law 162/1958, Qanun bi Sha'n Halah al-Tawari' [Law Concerning the State of Emergency], as amended ("Emerg. Law"), art. I. (unofficial English translation on file with author, courtesy of the Law Department at the American University in Cairo).

I3. Id. 
The declaration must state its reason, the region it covers, and the date of its application, and it must be referred to the People's Assembly for approval within fifteen days (or at the first meeting of the next Assembly if the Assembly is not in session at the time of the declaration). ${ }^{14}$ The specific powers the law grants the president are vast. Given their half century of nearly continuous operation, and the examples of their exercise that are to come, they merit full quotation. Upon a declaration of emergency the president may, "by an oral or written order," do the following:

(I) Restrict people's freedom of assembly, movement, residence, or passage in specific times and places; arrest suspects or [persons who are] dangerous to public security and order [and] detain them; allow searches of persons and places without being restricted by the provisions of the Criminal Procedure Code; and assign anyone to perform any of these tasks.

(2) Order the surveillance of letters of any type; supervise censorship; seize journals, newsletters, publications, editorials, cartoons, and any form of expression and advertisement before they are published, and close their publishing places.

(3) Determine the times of opening and closing public shops, and order the closure of some or all of these shops.

(4) Confiscate any property or building, order the sequestration of companies and corporations, and postpone the due dates of loans for what has been confiscated or sequestrated.

(5) Withdraw licenses of arms, ammunitions, explosive devices, and explosives of all kinds, order their submission, and close arms stores.

(6) Evict some areas or isolate them; regulate means of transport; limit means of transport between different regions. ${ }^{15}$

No aspect of Egypt's emergency rule has been more controversial than the powers specified in the first of the six paragraphs set out above. The "provisions of the Criminal Procedure Code" from which this paragraph exempts the president during a declared emergency are provisions that, inter alia, require warrants for searches and seizures and limit postarrest detention. ${ }^{16}$ The government exercises these exceptional powers routinely and robustly,

14. Emerg. Law art. 2.

15. Emerg. Law art. 3.

16. See Sadiq Reza, Egypt, in Criminal Procedure: A Worldwide Study 107, 114-22 (Craig Bradley ed., 2d ed. 2007). 
and human-rights groups and other nongovernmental organizations criticize that exercise and the very existence of the powers regularly and strenuously. Reports of mass arrests, incommunicado and prolonged detentions without trial, and torture through the exercise of these powers are routine. ${ }^{17}$

The Emergency Law also authorizes the creation of State Security Courts to hear violations of emergency orders and ordinary criminal offenses the president refers to them. ${ }^{18}$ The courts established pursuant to this authorization have been another of the most visible and controversial features of emergency rule in Egypt. A presidential decree of 1981, still in effect, refers a variety of ordinary crimes to these courts; among them are crimes concerning state security, crimes of public incitement (including by newspapers), and crimes involving public demonstrations and gatherings. ${ }^{19}$ The decree also says that any crimes that are not specifically listed but are connected with those listed are included in the referral. The Emergency Law provides for judges of the ordinary judiciary to preside in these courts, but it also allows the president to seat military judges in their place. ${ }^{20}$ These courts are to follow the rules of ordinary procedure, but different procedural rules may be dictated by presidential order. ${ }^{2 t}$ Verdicts in these courts are subject to ratification by the president; otherwise they are unappealable. ${ }^{22}$

17. For only one recent report, see Amnesty International, Egypt: Systematic Abuses in the Name of Security, Apr. 2007, available at http://amnesty.org/resources/Egypti/pdf/ 2007_04_amnesty_international_egypt_report.pdf.

18. Emerg. Law arts. 7, 9.

19. Pres. Decree $\mathrm{I} / 198 \mathrm{I}$, as amended by Pres. Decree $\mathrm{I} / 2004$.

20. Emerg. Law art. 7.

21. Emerg. Law arts. 7, ro.

22. Emerg. Law art. 12. The emergency State Security Courts should not be confused with the "permanent" State Security Courts that the People's Assembly created in 1980 and abolished in 2003. Those State Security Courts had been created pursuant to a constitutional provision that authorizes the establishment of courts of state security (art. 171), during the brief window of time between 1980 and 1981 when the country was not in a declared state of emergency and, accordingly, there were no "emergency" State Security Courts. Those courts had exclusive jurisdiction over felonies of state security, terrorism, explosives, bribery of public officials, and misappropriation of public funds, and they were apparently used mostly to try terrorism offenses that were created by sweeping 1992 legislation. Under the 2003 law that abolished those courts, all cases that were pending in them were transferred to specialized chambers of ordinary criminal courts. Reza, supra note 16 , at 109 . 


\section{Military Justice and Other Exceptional Authority}

Several other exceptional courts, all of them short-lived, were spawned by the 1952 Free Officers Revolution, which marks the beginning of the modern Egyptian state. These included a Court of Treason, set up in 1952 to try people accused of personal corruption or other obstruction of the new political order; a special military court, set up in 1953 to try Egyptian communists (on the ground of seditious libel); a Revolution Court, another military court, established in 1953 with a broad mandate to try crimes against the political order or the revolution; and People's Courts, established in 1954 to try members of the Muslim Brotherhood, the main Islamist group in Egypt at the time, after an unsuccessful assassination attempt on Nasser that was blamed on that group. ${ }^{23}$ That these courts were established to avoid the ordinary judiciary was explicit; the ruling military junta candidly noted its mistrust of the ordinary judiciary in dealing with the Muslim Brotherhood and its desire to conduct trials free of the constraints of ordinary procedure. ${ }^{24}$ (Ordinary criminal procedure was well established by then, through legislation including a 1937 Penal Code and a 1950 Criminal Procedure Code, both of which remain in force today, and a multi-level court system patterned on the French judiciary. $\left.{ }^{25}\right)$ Military judges presided in these exceptional courts, rules of procedure were loose or nonexistent, crimes and sentences were ill-defined, appeals were restricted, and the desired convictions were mostly obtained. ${ }^{26}$

These post-revolution exceptional courts solidified the basis, originally established by martial law under the British, for the 1958 Emergency Law. They also helped establish the separate system of military justice that has evolved and been much utilized to try civilians over the same period. The constitution provides for a system of military justice, and a 1966 law establishes that system. ${ }^{27}$ Under that law and subsequent amendments, the president can refer civilians to military courts for felonies that pertain to state security and all crimes during a state of emergency. ${ }^{28}$ Judges in these courts are military officers, and as with emergency-court judges their

23. Brown, supra note 3 , at 78-81; Seif el-Islam, supra note 8 , at 375 .

24. Brown, supra note 3 , at $77-78$.

25. See Reza, supra note 16 , at $106-07$.

26. Brown, supra note 3 , at $78-81$.

27. Egypt. const., art. 183; Law 25/1966, Qanun al-Ahkam al-Askariyah [Code of Military Justice].

28. Mil. Code arts. 6-7; Penal Code arts. 77-102(bis)-F. 
verdicts must be ratified by the president; an April 2007 amendment also provides for limited appellate review by a new Supreme Court of Military Appeals. ${ }^{29}$ According to one report, some 1,033 civilian defendants were tried in military courts between just the years 1992 and 2000 , resulting in 92 death sentences and 644 prison terms. ${ }^{30}$

\section{The 2007 Constitutional Amendments}

Thirty-four of the 2II articles in Egypt's constitution were amended in March 2007, via legislation that President Mubarak proposed in December 2006, the People's Assembly passed hurriedly on March I9, 2007, and the Egyptian people reportedly endorsed by referendum a week later. ${ }^{31}$ Among the amendments is a new article 179 that reads as follows:

The State shall be responsible for protecting security and public order from the dangers of terror. The law will set stipulations concerning procedures for investigation and identification of suspects which the state deems necessary in confronting these dangers, provided that the procedure stipulated in the first clause of article $4 \mathrm{I}$ and 44 and the second clause of article 45 of Constitution [shall] not obstruct such an effort. All will be carried out under the oversight of the judiciary.

The President has the right to refer any crime of terrorism to any judicial authority under the Constitution or the law. ${ }^{32}$

That the purpose of this new provision was to strengthen the emergency powers of the president was obvious; government officials acknowledged as much, even as they insisted that the amendments as a whole constituted a step toward democracy. ${ }^{33}$ The new article 179 accomplishes that purpose

29. Mil. Code art. 97; Law 16/2007.

30. Maye Kassem, Egyptian Politics: The Dynamics of Authoritarian Rule 4o (2004).

31. See Nathan J. Brown, Michele Dunne, \& Amr Hamzawy, Egypt's Controversial Constitutional Amendments, Carnegie Endowment for Int'l Peace, Mar. 23, 2007, available at http://www.carnegieendowment.org/files/egypt_constitution_webcommentaryor.pdf; Michael Slackman, Charges of Vote Rigging as Egypt Approves Constitution Changes, N.Y. Times, Mar. 28, 2007, at A8.

32. Egypt. const., art. 179 (quoted in Brown, Dunne \& Hamzawy, supra note 31, at 13 (Dina Bishara trans.)). The previous text of the article described the responsibilities and regulation of an obsolete government official, the Socialist Public Prosecutor. See Brown, Dunne \& Hamzawy, supra note 31, at 2.

33. See, e.g., Michael Slackman, As Egypt Votes on Laws, Cynicism Rules the Street, N.Y. Times, Mar. 26, 2007, at Arr. 
in two ways. First, the constitutional provisions from which it exempts the state's antiterrorism efforts-"the first clause of article $4 \mathrm{I}$ and 44 and the second clause of article 45"-are Egypt's constitutional protections against, respectively, warrantless arrest and detention, warrantless home entry, and warrantless surveillance or seizure of correspondence. Recall that the 1958 Emergency Law exempted the president from honoring the analogous search-and-seizure protections of the country's Criminal Procedure Code; the new article 179 constitutionalizes that exemption, and thus insulates it from constitutional review. Second, and in similar fashion, the last sentence of the new article 179 constitutionalizes the president's power to refer terrorism offenses to the emergency courts or military courts. Previously that power was only statutory, specifically under the Emergency Law and the Code of Military Justice. And the constitutionality of that power had been challenged in the courts, as we will see in part II. But it too is now ostensibly insulated from constitutional review.

This new emergency provision was not entirely unexpected. Promises to repeal the 1958 Emergency Law have accompanied each extension of it in recent years, and during his 2005 campaign for reelection Mubarak had pledged to work toward constitutional amendments that would, inter alia, enable a replacement of that law. ${ }^{34}$ Nor is the nature of the envisioned replacement any secret. In the same campaign, Mubarak had promised a law focusing exclusively on terrorism; Egypt's prime minister repeated the promise in 2006, in conjunction with urging the most recent extension of emergency; and the envisioned antiterrorism law was part of the government's explanation and rationale for the new article $179 .{ }^{35}$ Not surprisingly, however, nongovernmental observers are united and emphatic in their view of the new constitutional provisions, particularly the new article 179 . Focusing specifically on that article (and writing before the new amendments passed), Amnesty International deemed the new provisions "the most serious undermining of human rights safeguards in Egypt since the state of emergency was re-imposed in 1981." ${ }^{36}$ Human Rights Watch has

34. See Michael Slackman, Egypt Renews Emergency Detention Law, N.Y. Times, May I, 2006, at A3.

35. Id.; see also Brown, Dunne \& Hamzawy, supra note 3I, at 2; Statement of Prime Minister Ahmed Nazif, Apr. 2, 2007, available at http://constitution.sis.gov.eg/en/new2oo.htm.

36. Amnesty International, Egypt: Proposed Constitutional Amendments Greatest Erosion of Human Rights in 26 Years, Mar. 18, 2007, available at http://news.amnesty.org/index/ ENGMDEI20082007. 
deemed article 179 "particularly troubling" given the broad definitions of terrorism that already exist in Egypt's Penal Code. ${ }^{37}$ And the ultimate conclusion about the new article 179 is as inescapable as it is obvious. By embedding specific powers of emergency rule in the constitution, the government has made de jure what was been de facto for decades: emergency rule in Egypt is permanent. ${ }^{38}$ And by doing so, the regime has clearly taken at least as much with one hand what it has promised to give away with the other: with core emergency powers now embedded in the constitution, the promised repeal of the 1958 Emergency Law will be as simple a matter as it is a meaningless one.

\section{THE PURPOSES AND EXERCISE OF EMERGENCY POWERS AND OTHER “EXCEPTIONAL" AUTHORITY IN EGYPT}

\section{A. Purposes: Asserted vs. Apparent}

What explains the extensive array and extended use of emergency powers and other exceptional authority in Egypt? Necessity is of course the mother of exceptional measures; that Egyptian leaders have consistently cloaked emergency declarations and the exercise of commensurate powers in its garb is therefore no surprise. In 1954, Nasser cited the need "to secure the Revolution first" to justify the exceptional People's Courts. ${ }^{39}$ More recently,

37. Human Rights Watch, Egypt: Don't Enshrine Emergency Rule in Constitution, Mar. 26, 2007, available at http://hrw.org/english/docs/2007/03/26/egypti5566.htm. For instance, one definition of terrorism is to operate or assist any group that calls for "encroaching on the personal freedom of citizens" or "impairing the national unity or social peace." Penal Code art. 86(bis). See also Amnesty International, Systematic Abuses in the Name of Security, supra note 17, at IO-11 (calling on Egypt to review its existing definitions of terrorism and to define terrorism in conformity with principles of legality and individual responsibility in the envisioned new law).

38. See also International Commission of Jurists, International Panel Concludes Mission on Counter-terrorism Measures in the Middle East, June 7, 2007, available at http:// www.icj.org/IMG/EJP-PREgypt_2.pdf (noting concerns about the permanency of Egypt's emergency rule and its enshrinement in the new constitutional provisions); Brown, Dunne \& Hamzawy, supra note 31 , at 2 (arguing that it is "difficult to challenge" the interpretation that article 179 "enshrine[s] what was technically a temporary (if ongoing) state of emergency as a permanent part of Egypt's political structure and wall[s] off security practices from constitutional oversight").

39. Brown, supra note 3 , at 77 . 
Mubarak explained in 1998 that renewing the emergency law was necessary "in order to confront terrorism [and] protect democracy and stability." ${ }^{40}$ In 2000 , arguing for the three-year extension of the law that passed that year, the minister of the interior insisted emergency rule was "an indispensable deterrent ... [to] guard . . . against the criminal forces who are still intent on seizing all possible opportunities to incite unrest and hit national interests." ${ }^{41}$ Three years later, Egypt's prime minister assured the parliament that another extension was needed "to ensure and protect the nation and to abort sabotage attempts." 42 Three years later still (in 2006), a different prime minister explained that the most recent extension, for two years, was needed "to protect the citizens and face the terror cells that have not quelled until now" and that the country could not afford to await the promised new antiterrorism law. ${ }^{43}$ More broadly, attempting in 2003 to justify what was then twenty-two years of continuous emergency rule, Egypt stated the following to the UN Human Rights Committee, which the year before had said it was "disturbed" by "the semi-permanent state of emergency" in Egypt and had called on the country to "consider reviewing the need to maintain [it]":

In the circumstances that faced the country following the assassination of President Mohamed Anwar al-Sadat [in 198I], Egypt was forced to declare a state of emergency, which was subsequently extended in order to deal with the phenomenon of terrorism and to protect the security and stability of society. ${ }^{44}$

In other words, not surprisingly, the past half century of nearly continuous emergency rule in Egypt has been essential to the very existence of the state.

That the modern Egyptian state and citizenry have endured more than their share of violence from regime opponents over the decades, particularly

40. Kassem, supra note 30 , at 56 .

4I. Id. at 38 .

42. Mona El-Ghobashy, Unsettling the Authorities: Constitutional Reform in Egypt, Middle E. Rep., Spring 2003, at 28, 33.

43. Slackman, supra note 34 .

44. Jean Allain, International Law in the Middle East 209 (2004). The committee had also expressed concerns about Egypt's emergency rule and practices in 1993, noting among other things the "multitude of special courts" and the norm that such courts exist only "as an exceptional measure." Id. at 208. 
from the Muslim Brotherhood and other Islamist groups, is undeniable. How much of that violence has been a consequence of repressive measures, rather than just a cause for them, is unclear. ${ }^{45}$ But either way, it seems undeniable that the state has exercised its emergency powers and military courts to suppress nonviolent as well as violent political opposition, again especially from Islamist groups, particularly in the twenty-six years of rule under current President Mubarak. Nasser had effectively suppressed the Muslim Brotherhood in the I950s, and the group had remained relatively quiet during the 1960s; during the 1970s, Sadat even worked to accommodate it. ${ }^{46}$ Mass arrests of the group followed Sadat's 1981 assassination, which was blamed on Islamists (and which occasioned the declaration of emergency that has been renewed continuously since), but in 1984 the group emerged as a nonviolent political force, winning eight seats in the People's Assembly. The next year, Mubarak's security forces denied a march permit to an Islamist activist, sealed off a mosque from which the march was to commence, and detained more than five hundred of the expected demonstrators. ${ }^{47}$ Mosques-where Islamist leaders held political rallies-were again sealed by security forces before the 1987 elections, and some two thousand members and supporters of the Brotherhood were arrested on the eve of that election. ${ }^{48}$ (The Brotherhood nevertheless won an unprecedented thirty-eight seats that year, 9 percent of the national vote ${ }^{49}$ ) Before the 1995 parliamentary elections, security forces arrested fifty-four prominent leaders of the Brotherhood and convicted them in military-court trials; only one Islamist-oriented candidate won a seat that year. ${ }^{50}$ Before the 2000 elections, twenty Islamists were arrested and charged with "working to revive the outlawed Muslim Brotherhood"; they too were convicted in military trials. ${ }^{51}$ (As one Egyptian journalist put it that year, "Mass [Muslim] Brotherhood trials have become something of an election-year tradition in Egypt." ${ }^{\prime 2}$ ) And the

45. See, e.g., Kassem, supra note 30, at 153-56 (discussing Islamist violence in the 1980 os and 1990 as retaliation for state repression).

46. Id. at 140-43.

47. Id. at 148-49.

48. Id. at 150, 152 .

49. Id. at $148,151-52$.

so. Id. at 38 .

5I. Id.

52. Id. 
pattern of preelection arrests of Islamists, among many others, repeated itself again in $2005 .^{53}$

Nonviolent political opposition other than that by Islamists has also been suppressed by emergency powers and military courts in Egypt. In particular, liberal critics of the regime have never been well tolerated by Egypt's leaders, and Mubarak's use of exceptional authority to silence such critics has been more than evident. Throughout the 1990s, military courts were used not just to try Islamists but also to intimidate journalists and other vocal regime critics: in several incidents, for instance, authors of articles on military topics were accused of crimes in those courts and interrogated, only to be sent home with warnings to exercise more discretion and to have the charges against them dropped..$^{54}$ Human-rights organizations and other observers document dozens, if not hundreds, of such "political" arrests by security forces each year. Even the referendum on the March 2007 constitutional amendments resulted in allegations of election-eve arrests of regime opponents by security forces. ${ }^{55}$ But perhaps the most prominent recent uses of emergency powers to suppress liberal political opposition were the 1998 arrest and interrogation, and a threatened emergency-court trial in 2000, of Hafez Abu Saada, the secretary general of the prominent Egyptian Organization for Human Rights, and the 20oI emergency-court trial and conviction of Saad Eddin Ibrahim, an internationally-known professor at the American University in Cairo and founder of another Egyptian human-rights organization, the Ibn Khaldun Center for Development Studies. Both men were (and are) prominent regime critics; both were charged with receiving foreign money for the purpose of harming Egyptian national interests. Abu Saada's case was not ultimately prosecuted-he had been released soon after his 1998 arrest, was in France seeking asylum when the case was reopened in 2000 , and has since returned to Egypt - but neither has the charge been formally withdrawn. Ibrahim, however, was convicted along with several colleagues in May $200 \mathrm{I}$ and sentenced to seven years of hard labor. ${ }^{56}$

53. Mona El-Ghobashy, Egypt Looks Ahead to Portentous Year, Middle East Report Online, Feb. 2, 2005, at II, available at http://www.merip.org/mero/meroozozos.html.

54. Brown, supra note 3, at II4.

55. See Human Rights Watch, supra note 37.

56. Good discussions of these cases are in Moustafa, supra note 3, at $183,185,190-96$, 202-05; Kassem, supra note 30, at 170-7I. As noted in the next section, Ibrahim was subsequently retried and acquitted by a court of the ordinary judiciary. 
Still another example of the current regime's use of emergency powers for political purposes is the $200 \mathrm{I}$ arrests and emergency-court prosecutions of over fifty young men for prostitution and "debauchery"-i.e., being practicing homosexuals. ${ }^{57}$ Convictions and sentences of up to five years quickly issued; but why were the defendants tried in emergency state security courts? The lead charge against them was "contempt for religion," which is proscribed by a provision of the ordinary penal code, article $98(f)$, that is often used for such prosecutions. Whatever threat to state security the government asserted the defendants posed was clearly of a different order and caliber from the threat the government saw in the work of liberal regime critics like Hafez Abu Saada and Saad Eddin Ibrahim. But clearly too, prosecuting homosexuals pleases and appeases the regime's main opponents besides liberal critics: Islamists. ${ }^{58}$ So too, for that matter, can prosecuting liberal regime critics themselves, since those targets might also happen also to be liberal critics of Islamists. ${ }^{59}$ Pursuing these cases in state security courts of course enhances the government's control over the prosecutions and the outcomes (though it does not guarantee the outcomes, as we will see in the next section). Emergency powers and other exceptional authority thus provide and serve as a key tool for the government to consolidate and maintain its political power.

\section{B. Limitations on Egypt's Emergency Powers}

The exercise of exceprional authority in modern Egypt has not been entirely unchecked. Indeed, the country's ordinary judicial and quasi-judicial institutions have limited executive emergency prerogatives from the earliest years of their operation. Two years after the 1946 creation of a Council of State (Majlis al-Dawla), modeled on France's Conseil d'Etat, the Council's Administrative Court reversed government decisions to close down newspapers pursuant to emergency decrees. ${ }^{60}$ The same court, in I95I, questioned the legality of the 1948 dissolution of the Muslim Brotherhood, and in 1952 it cancelled arrest warrants the government had issued against two radical critics of the regime. ${ }^{61}$ More recently, state security

57. See Kassem, supra note 30, at $176-77$.

58. See Kassem, supra note 30, at 177.

59. See David S. Sorenson, The Dynamics of Political Dissent in Egypt, 27 Fletcher F. World Aff. 207, 222, 225 (2003).

6o. Brown, supra note 3 , at 72 .

61. Id. at $72-73$. 
courts have themselves checked the government's exercise of emergency powers: on several occasions in the 1980s and 1990s, Cairo's emergency State Security Court acquitted defendants tried there, and among the grounds for these acquittals was the government's use of torture against the defendants. ${ }^{62}$ And in 2003 the Court of Cassation, Egypt's highest court of ordinary (non-constitutional) civil and criminal justice, retried Saad Eddin Ibrahim and his colleagues and acquitted them, in a ruling that included sharp criticism of the prosecution and the government generally. ${ }^{63}$

But neither has the judiciary has been entirely hostile to the government's use of emergency powers. The Supreme Constitutional Court, established in 1979 and armed with the power of judicial review, ruled in 1984 that the appeal restrictions and other procedures of the emergency State Security Courts do not violate the constitution. ${ }^{64}$ That court also appears unwilling to limit executive use of the military courts, which President Mubarak turned to especially in the early I990s after an upsurge in Islamist violence and his defeats in the emergency courts. In 1992, after Mubarak began transferring the cases of Islamists to military courts, an administrative court deemed the transfers unauthorized by the 1966 Code of Military Justice, finding that law allowed only the transfer of entire categories of cases rather than individual cases. The Supreme Administrative Court reversed the ruling, and the Supreme Constitutional Court too interpreted the law to allow the individual transfers. ${ }^{65}$ A separate challenge to the constitutionality of transferring civilians to military courts was filed with the Supreme Constitutional Court in 1995, but no ruling ever issued; nor, had one issued, was it expected to find the practice unconstitutional, even before the new article 179 arguably silenced transfer challenges by constitutionalizing the president's power to transfer terrorism cases "to any judicial authority."66 More broadly, the Supreme Constitutional Court has indicated its recognition of a line between judicial questions and political ones, or "acts of sovereignty," and

62. And among these defendants was Sheikh Omar Abdel Rahman. See id. at 98-99, I13-I4; Kassem, supra note 30, at 36-37.

63. See Moustafa, supra note 3 , at 203-04. There is no provision for the retrial of emergency-court trials, but the government apparently agreed to the retrial, presumably because of the international condemnation it had received for the initial trial. See id.

64. See id. at 104-06.

65. Brown, supra note 3, at II4-15; Seif el-Islam, supra note 6, at 364; Moustafa, supra note 3 , at 174-75.

66. Moustafa, supra note 3 , at 175 . 
a willingness to defer to the executive branch on matters falling into the latter category; and in that category the court apparently places domestic as well as foreign matters that relate to "the security and well-being of the country." 67 Such deference is, of course, now mandated by the new article 179, at least insofar as powers of search and seizure and the president's transfer of cases to the emergency and military courts are concerned.

Why has Egypt's Supreme Constitutional Court not limited the government's use of exceptional authority? That military courts, state security courts, and the power to declare an emergency are all permitted by the constitution itself is one answer. Another, however, is that an attempt by that court to curb executive power in those arenas might prompt the regime to take steps to undermine the court's power-a power that has steadily increased in recent decades, and that is increasingly being used to pursue a liberal agenda in other arenas, including electoral reform and freedom of the press. ${ }^{68}$ In other words, the court might maintain (and enhance) its power to effectuate liberalizing political reforms by not challenging the government's use of exceptional authority to pursue its political opponents. The existence and use of emergency rule and military courts for illiberal political purposes by the Egyptian government have thus arguably enabled political liberalization in other spheres. ${ }^{69}$

\section{Islamist Targets of Egypt's Emergency Powers}

Workers, political activists, counterrevolutionaries, Communists, homosexuals - all these and more have been targeted by emergency and military powers in modern Egypt. But nowhere has the exercise of emergency authority in Egypt been more consistent and consequential than with the regime's Islamist opponents. We have seen that violence by the Muslim Brotherhood made them an early target of martial law, and that their nonviolent political opposition led to the use of emergency powers and military courts to suppress them more recently. Let us consider some recent events in more detail, focusing on the connection between exceptional authority and Islamist violence. In the I980s, Islamists were making gains not only in the electoral arena but also in professional societies and among student unions. In 1984, for instance, the Muslim Brotherhood won seven of the

67. Brown, supra note 3 , at 121 .

68. See Moustafa, supra note 3, at 51, 106, 140-45, 154-64.

69. See id. at $8,5 \mathrm{I}-52,119,175-77$. 
twenty-five seats in the country's Doctors Syndicate, and in 1987 it won fifty-four of the sixty-three seats in the Engineers Syndicate. ${ }^{70}$ The government's mass arrests of Brotherhood members in the summer of 1987 , before that year's election, were thus a response to more than simply seats in parliament. Islamists were becoming a legitimate and powerful force in civil society, and a nonviolent one to boot.

By then, however, additional Islamist organizations had cropped up in Egypt, including one called al-Jihad and another called the Islamic Group (al-jama'a al-Islamiyya); these two groups formed a consultative council that was led by popular cleric Sheikh Omar Abdel Rahman. That sheikh was among those targeted by the security crackdown of the mid-1980s. In 1986 he was placed under house arrest, in 1989 he was exiled, and after stints in Afghanistan and the Sudan he ended up preaching at a mosque in Brooklyn-and, finally, in federal prison, convicted of conspiracy to bomb bridges, tunnels, and landmark buildings in New York City. Ayman al-Zawahiri, meanwhile, was a radical leader of Islamic Jihad and one of the hundreds of people arrested immediately after Sadar's I98I assassination. Ultimately convicted only of weapons charges, al-Zawahiri was held in prison for three years and, by many accounts, tortured severely there by security forces. Upon his release he went to Afghanistan to join the fight against the Soviets, returning to Egypt in the early 1990 s with the military knowledge and tactics he had learned in Afghanistan. President Mubarak was trying Islamists in the military courts by then, and we have seen that the Supreme Constitutional Court upheld these trials. Islamist violence increased, al-Zawahiri fled the country after being implicated in it, and in November 1997 came the massacre of fifty-eight tourists and four Egyptians in Luxor. Al-Zawahiri was tried in absentia in a military court for orchestrating that attack, and convicted and sentenced to death in 1999. By then, however, he had joined with Osama bin Laden in declaring war against a different enemy, namely "Jews and Crusaders"; that is the war in which the attacks of September II, 200I, were one battle. ${ }^{71}$

70. Kassem, supra note 30 , at 152

71. See also Hany Besada, Egypt's Constitutional Test: Averting the March Toward Islamic Fundamentalism, Centre for International Governance Innovation, Working Paper No. 28 (Aug. 2007), available at http://www.cigionline.org, at 9 ("Some [Egyptian political analysts] have ... gone so far as to indicate to American officials that September II was born in Egyptian jails[,] where [Muslim Brotherhood] members were awaiting sentencing on terrorism-related charges."). 
The 1997 Luxor attack cost the Islamists considerable legitimacy with the Egyptian populace; counting that attack, some 1,300 Egyptians and foreigners were killed by Islamist violence from 1990 to $1997 .^{72}$ Even the Islamists, then represented primarily by the Islamic Group, came to see the political error of militant responses to the government's repression, and they declared a cease-fire in $1999 .{ }^{73}$ Nevertheless, by 200I, humanrights organizations estimated the number of Islamists and other political prisoners who were detained under emergency powers at between 13,000 and 20,000. ${ }^{74}$ And the cycle of Islamist violence and government crackdown via emergency measures shows no sign of abating. Bombings at tourist resorts in the Sinai peninsula in 2004, 2005, and 2006, each of which killed dozens of people (thirty-four, eighty-eight, and twenty-three, respectively), each resulted in the prompt arrests of hundreds of suspects by security forces. ${ }^{75}$ Today, Amnesty International estimates the number of security detainees in Egypt's jails at 18,000. ${ }^{76}$

\section{THE ROLE AND FUTURE OF EMERGENCY RULE IN EGYPT}

Viewed in light of the recent Islamist violence, the government's most recent extensions of the state of emergency and exercise of its powers might appear to have good reason. But the recent constitutional amendments make it clear that the government has no intention of ending emergency rule. And the endlessness of emergency in Egypt confirms the utterly unexceptional—though utterly crucial-role that emergency powers have played in the country over the past one hundred years. In its use to suppress nonviolent political opposition as much as violent opposition,

72. Id. at I5s.

73. Id. at 157. It was a statement about that cease-fire by the imprisoned Sheikh Omar Abdel Rahman that his attorney, Lynne Stewart, released to the press in the summer of 2000.

74. U.S. State Department, 20or Country Reports on Human Rights Practices: Egypt, available at http://www.state.gov/g/drl/rls/hrrpt/20ol/nea/8248.htm; Kassem, supra note 30 , at 156 .

75. These bombings have been attributed to yet a different Islamist group, Tawhid walJihad (Unity and Holy War), which is allegedly affiliated with Al-Qaeda.

76. Amnesty International, supra note 17 , at 3 . 
so-called exceptional authority has been a product of the broader project of creating the modern Egyptian state and a vehicle for that project.

The very conception and structure of state in Egypt has been, since the modern state-building project began there in the late $1800 s$, that of a centralized and executive-dominated government. Both the 1923 and the 1971 constitutions - respectively, the first and the last of Egypt's several twentiethcentury constitutions - confirmed the domination of the state by the presidency. ${ }^{77}$ The legal system that was established during that period and remains in place today was, accordingly, not designed to create constraints on government. Rather, courts and laws were created in order to strengthen the state's domination of society. ${ }^{78}$ Emergency powers and other exceptional authority are both consistent with this aim and powerful tools for achieving it. Egypt's rulers have, in other words, used emergency rule much as their British predecessors used martial law: to assert and maintain control over the Egyptian populace at large. In the authoritarian regime that is modern Egypt, emergency powers, military courts, and their use have thus been not exceptional authority but ordinary authority. ${ }^{79}$

The future of emergency rule in Egypt is, then, inseparable from the country's political evolution. In one view, the direction of that evolution before the 2007 constitutional amendments may have been inexorably, if haltingly (and even unwittingly), toward greater democratization and popular participation and, commensurately, less authority for the executive-dominated state apparatus. ${ }^{80}$ Whether the 2007 amendments advance or impede such movement remains to be seen; at least one early and

77. Brown, supra note 3, at 79, 82; see also El-Ghobashy, supra note 53, at 13 ("Egypt's rulers have always feared and loathed popular constitutionalism.").

78. Brown, supra note 3 , at 60 .

79. As such, Egypt's endless emergency may be more apparent, but, in the end, little different in kind, though dramatically different in application, from the long-standing "emergencies" in many of today's democracies. See Neocleous, The Problem with Normality, supra note 4, at 208 ("emergency measures, as state violence, are part of the everyday exercise of powers, working alongside and from within rather than against the rule of law, as part of a unified political strategy in the fabrication of social order.").

80. See Mona El-Ghobashy, Egypt's Paradoxical Elections, Middle E. Rep., Spring 2006, at 20, 29, available at http://www.merip.org/mer/mer238/elghobashy.html (discussing the potential gains for popular participation and regime opposition in recent rounds of elections despite regime efforts to limit such gains). 
authoritative view is not optimistic. ${ }^{81}$ Indeed, the entrenchment of emergency powers in the new article 179 might reflect nothing other than the regime's increasing skill at using the constitution to subvert constitutionalism and democracy. ${ }^{82}$ At the very least, presidential emergency powers are protected from encroachment by the judiciary in a way they have not been in the half century of nearly continuous operation of the 1958 Emergency Law.

The next development in emergency rule in Egypt will likely not be long in coming; with the current state of emergency set to expire in April 2008, the antiterrorism law that has been promised as its replacement is due to arrive any day. How that law defines terrorism and what powers it grants the president in the name of combating it will pinpoint both the future of emergency rule and the state of democracy in Egypt. But if the new law does not come in time, the likely result seems clear: the state of emergency can simply be extended again.

8I. See Brown, Dunne \& Hamzawy, supra note 3I, at I ("Taken together, the [2007] amendments and the process by which they were passed constitute an effort by the Egyptian regime to increase the appearance of greater balance among the branches of government and of greater opportunities for political parties, while in fact limiting real competition strictly and keeping power in the hands of the executive branch and ruling party.").

82. See Kristen Stilt, Constitutional Authority and Subversion: Egypt's New Presidential Election System, 16 Ind. Int'l \& Comp. L. Rev. 335 (2006) (discussing a similar effort in a 2005 constitutional amendment that established the principle of multi-candidate presidential elections). 